medRxiv preprint doi: https://doi.org/10.1101/2020.12.16.20247643; this version posted December 18, 2020. The copyright holder for this preprint (which was not certified by peer review) is the author/funder, who has granted medRxiv a license to display the preprint in perpetuity.

It is made available under a CC-BY-NC-ND 4.0 International license .

\title{
Publishing at any cost: a cross-sectional study of the amount that medical researchers spend on open-access publishing each year
}

Mallory K. Ellingson, Xiaoting Shi, Joshua J. Skydel, Kate Nyhan, Richard Lehman, Joseph S. Ross, Joshua D. Wallach

Mallory K. Ellingson, Doctoral student

Department of Epidemiology of Microbial Diseases, Yale School of Public Health, New Haven, CT, USA

Xiaoting Shi, Doctoral student

14 Department of Environmental Health Sciences, Yale School of Public Health, New Haven, CT, 15 USA

Joshua J. Skydel, Medical student

Tufts University School of Medicine

Kate Nyhan, Medical Librarian

Harvey Cushing/John Hay Whitney Medical Library; Department of Environmental Health

Sciences, Yale School of Public Health, Yale University, 333 Cedar St., New Haven, CT, USA

Richard Lehman, Honorary Senior Research Fellow

Joseph S Ross, Professor Internal Medicine, Yale School of Medicine; Department of Health Policy and Management, Yale School of Public Health; and Center for Outcomes Research and Evaluation, Yale-New Haven Health System, New Haven CT, USA

Joshua D Wallach, Assistant Professor

Department of Environmental Health Sciences, Yale School of Public Health and the Collaboration for Research Integrity and Transparency, Yale School of Medicine, New Haven, Connecticut, USA, 60 College Street, New Haven, CT, 06510, USA

\section{Corresponding author:}

40 Joshua D Wallach, MS, PhD

41 Assistant Professor

42 Department of Environmental Health Sciences

43 Yale School of Public Health

4460 College Street, $4^{\text {th }}$ Floor, Room 411

45 New Haven, CT, 06510 USA

46 Email: joshua.wallach@yale.edu 
medRxiv preprint doi: https://doi.org/10.1101/2020.12.16.20247643; this version posted December 18, 2020. The copyright holder for this preprint (which was not certified by peer review) is the author/funder, who has granted medRxiv a license to display the preprint in perpetuity. It is made available under a CC-BY-NC-ND 4.0 International license .

48 ORCID number: 0000-0002-2816-6905

49 Twitter: @JoshuaDWallach

50

51

52 Key words: Publishing; Article processing costs; Open access

53 Word count: 5125

54 Figures/Tables: 3/4 (3 Figures, 4 Tables)

55 References: 56

56 Appendix: none 


\section{ABSTRACT}

58 Objective: To estimate the financial costs paid by individual medical researchers from meeting

59 the article processing charges (APCs) levied by open access journals in 2019. To investigate the

60 emotional burden to researchers using a novel metric (the APC Twitter Whinge Score).

61 Design: Cross-sectional analysis.

62 Data sources: Scopus was used to generate two random samples of researchers, the first with a

63 senior author article indexed in the 'Medicine' subject area (i.e., general researchers) and the

64 second with an article published in the ten highest impact factor general clinical medicine

65 journals (i.e., high-impact researchers) in 2019. For each researcher, Scopus was used to identify

66 all first and senior author original research and review articles published in 2019. Researcher and

67 journal information was obtained from Scopus, institutional profiles, Journal Citation Reports,

68 publisher databases on APCs, the Directory of Open Access Journals, and individual journal

69 websites. Twitter searches were conducted to identify and classify APC-related tweets using a

70 novel APC Twitter Whinge Score.

71 Main outcome measures: Median APCs paid by general and high-impact researchers for all

72 first and senior author research and review articles published in 2019; additionally, we examined

73 median APCs paid by researcher gender, affiliation, training, and geographic region. APC

74 Twitter Whinge Score.

75 Results: There were 241 general and 246 high-impact researchers identified as eligible for our

76 study. In 2019, the general and high-impact researchers published a total of 914 (median 2,

77 interquartile range 1-5) and $1471(4,2-8)$ first or senior author research or review articles,

78 respectively. 42\% (384/914) of the articles from the general researchers and 29\% (428/1471) of

79 the articles from the high-impact medical researchers were published in fully open access 
medRxiv preprint doi: https://doi.org/10.1101/2020.12.16.20247643; this version posted December 18 , 2020. The copyright holder for this preprint (which was not certified by peer review) is the author/funder, who has granted medRxiv a license to display the preprint in perpetuity.

It is made available under a CC-BY-NC-ND 4.0 International license .

80 journals. The median total APCs paid by general researchers in 2019 was $\$ 191$ [£150]

81 (interquartile range $\$ 0-\$ 2500$ [£0-£1960]) and the median total paid by high-impact researchers

82 was $\$ 2900$ [ $£ 2274$ ] (interquartile range $\$ 0-\$ 5465$ [ $£ 0-£ 4285]$ ); the maximum paid by a single

83 researcher in total APCs was \$30115 [ $£ 23610$ ] and \$34676 [£27186], respectively. There were

84 no differences in total APCs paid by gender, affiliation, or training. However, high-impact

85 researchers from the Region of the Americas had a lower median total APCs paid than those

86 from other regions ( $\$ 1695$, interquartile range $\$ 0$ - \$3935) [£1329, £0-£3085] vs. \$4800, \$1888-

87 \$8290) [ $£ 3763$, £1480-£6500]; P<0.001). Among a sample of 195 APC-related tweets in 2019,

$88121(62.1 \%)$ were publicly resentful (with or without sweary language) of APCs, scoring in the

89 highest two categories of the APC-related Twitter Whinge Score.

90 Conclusions: Medical researchers in 2019 were found to have paid between 0 [ $£ 0$ ] and $\$ 34676$

91 [£27186] in total APCs. As journals with APCs become more common, it is important to

92 understand the cost to researchers, especially those who may not have the funding or institutional

93 resources to cover these costs, or we risk creating a pay-to-publish system that favors well-

94 resourced authors from well-resources institutions and areas of the world. We also present

95 evidence that these APCs may cause emotional damage to researchers, causing them to divert

96 effort to moaning on Twitter. We postulate that behind this behavior may lie hidden harmful

97 cycles of personal penury, domestic argument, insomnia, poor work relationships, inadequately

98 prepared coffee, and even the possible use of alcohol before tweeting. 


\section{What is already known on this topic:}

100 - Over the past 20 years, a new model of scientific publishing has emerged that relies on

101 digital publication rather than print distribution - open access publishing.

102 - Open access publishing has shifted part of the financial costs of publishing from

103 academic institutions to individual researchers and their funders, who are responsible for

104 article processing charges that can average $\$ 2000$ (£1568) to $\$ 3000$ (£2352) per article.

105 - In additional to the potential financial costs of publishing, anecdotal evidence suggests

106 that article processing charges may lead to emotional damage to researchers, causing

107 them to divert effort to moaning on Twitter.

\section{What this study adds:}

109 - Medical researchers could be paying as much as \$34676 [£27186] in total article

110 processing charges for their first and senior research and review articles each year.

111 - The majority of article processing charge related tweets are publicly resentful (with or

112 without sweary language) of these journal fees, scoring in the highest two categories of

113 the Twitter Whinge Score.

114 - As journals with article processing charges become more common, it is important to 115 understand the burden - financial and emotional - on researchers, especially those who 116 may not have the funding or institutional resources to cover these costs. 
It is made available under a CC-BY-NC-ND 4.0 International license .

\section{INTRODUCTION}

118

119

120

121 scientists across the world, ${ }^{1,2}$ the pressure to publish has only risen, as has the importance of

122 publications for employment, promotion, and tenure. ${ }^{3}$ Over the past decade, there has been a

123 striking growth in the number of scientific articles published per year, with nearly 2.5 million

124 scientific articles published in 2018 alone. ${ }^{4}$ The sheer quantity of scientific research being

125 published, the shift to predominantly electronic publishing, and a broad movement to make

126 scientific research more transparent has wrought a dramatic change in the landscape of scientific

127 publishing. 5,6 annual membership fee.

However, over the past 20 years, a new model of scientific publishing emerged that relied on digital "publication" rather than print distribution - open access publishing. ${ }^{5}$ Generally, open peer-reviewed journals. These journals have operated using a subscription model, generally owned and managed by a professional society or a medical publisher. Under this model, the cost to individual researchers, either to access articles or publish their own research in the journals, is minimal (although they contribute substantial in-kind effort through peer and editorial review). Instead, institutions pay subscription fees, which can reach millions of dollars for larger publishers, to gain access to articles for the institution's affiliates. ${ }^{7,8}$ Receipt of the $B M J$ is a compulsory benefit imposed on members of the British Medical Association in return for an access journals forgo subscriptions for their online content and instead make research available to scholars without institutional subscriptions and to the general public. With no revenue from 
141 subscriptions (or from prescription drug advertisements), some open access journals established

142 a new business model built around article processing charges (APCs). ${ }^{5}$ Compared to the

143 subscription journals, the APC model has shifted part of the financial burden of publishing from

144 academic institutions to individual researchers and their funders, who are responsible for APCs

145 that average $\$ 2000$ (£1568) to $\$ 3000$ (£2352) per article. ${ }^{9,10}$ In this way, everyone can eat the

146 picnic, but those who provide the food do so at their own cost and are additionally charged for

147 bringing it to the picnic site.

With almost 5000 open access journals following the APC business model, ${ }^{11}$ researchers

149 are increasingly having to consider if and how they can afford to publish their research in open

150 access journals with the limited pool of funds available. While the vast majority of medical

151 researchers are supportive of the concept of open access publishing, over half listed financial

152 barriers as the primary reason they would choose not to publish in open access journals. ${ }^{12}$

153 Although APCs can be covered with funds from research grants or by funders directly, not all

154 research is grant funded, the structure and amount of funding that comes from grants can vary by

155 field, and the ability or willingness of funders to cover APCs differs by region. ${ }^{10,13}$ Additionally,

156 early career researchers or under-represented minority (URM) researchers may have more

157 limited access to grant funding or institutional funds to cover APCs, as do researchers in less

158 lucrative clinical fields like primary care and public health. ${ }^{14-16}$ While fee waivers are sometimes

159 granted to researchers in low- and middle-income countries or without funding, discounted APCs

160 may still be prohibitive for many researchers. ${ }^{17,18}$

161 If financial barriers play such a substantial role in scientists' decisions on where to

162 publish, it is important to investigate the potential financial costs of publishing on individual

163 medical researchers. Therefore, we aimed to estimate how much individual medical researchers 
medRxiv preprint doi: https://doi.org/10.1101/2020.12.16.20247643; this version posted December 18, 2020. The copyright holder for this preprint (which was not certified by peer review) is the author/funder, who has granted medRxiv a license to display the preprint in perpetuity.

It is made available under a CC-BY-NC-ND 4.0 International license .

164 spend on APCs over the course of a year for both a general sample of medical researchers as well

165 a sample of researchers who published in the highest impact factor clinical medicine journals in

166 2019. To measure the emotional burden of APCs on researchers, we also evaluated APC-related

167 tweets using a novel metric (The APC Twitter Whinge Score).

169 METHODS

170 Part 1: Estimating article processing charges

171 Study design and sample

172 We conducted a cross-sectional analysis of two random samples of medical researchers to

173 obtain estimates of the average amount of money that individual researchers spend on APCs each

174 year. We used Scopus to identify 250 general medical researchers and 250 medical researchers

175 who published at least one article in one of the ten highest impact factor general clinical

176 medicine journals.

178 Generating a sample of general and high-impact researchers

179 First, we downloaded the first 20000 English language research or review articles

180 published in a journal indexed in the Scopus subject area of 'Medicine' in 2019 (Figure 1), the

181 maximum data export permitted through the Scopus portal. Next, we used Scopus to identify all

182 research or review articles published in the top ten highest impact factor clinical medicine

183 journals in 2019 (according to the Journal Citation Report (JCR): ${ }^{19}$ New England Journal of

184 Medicine (NEJM), Lancet, Journal of the American Medical Association (JAMA), British

185 Medical Journal (BMJ), JAMA Internal Medicine, Annals of Internal Medicine, PLOS Medicine,

186 BMC Medicine, Mayo Clinic Proceedings, and Canadian Medical Association Journal). For 
medRxiv preprint doi: https://doi.org/10.1101/2020.12.16.20247643; this version posted December 18, 2020. The copyright holder for this preprint (which was not certified by peer review) is the author/funder, who has granted medRxiv a license to display the preprint in perpetuity.

It is made available under a CC-BY-NC-ND 4.0 International license .

187 each sample, we used a random number generator to select 500 articles. However, given the

188 broad nature of the search utilized, some articles randomly selected did not fall under the

189 category of "general clinical medicine," or were other article types misclassified as research or

190 review articles. Therefore, the first 250 articles determined to be eligible were retained for each

191 sample (i.e., 250 general medicine articles and 250 high-impact medicine articles).

192 Next, we identified the senior-most (i.e., last) author of each research or review article

193 contained in the sample (hereafter, index researcher). Potential duplicate researchers were

194 verified and removed through a Scopus and/or Google scholar search of the researcher's name. If

195 authorship was listed as a group, without any designated individuals, the manuscript was

196 excluded from the sample. If a group authorship was listed as the senior author, the senior-most

197 individual author on the article was used.

199 Data collection

200 Three investigators (MKE, XS, JJS) independently abstracted data, and to ensure data

201 quality, approximately $20 \%$ of each sample was abstracted in duplicate to verify consistency. All

202 uncertainties were discussed with a fourth investigator (JDW). All data abstraction and

203 validation were conducted between April $22^{\text {nd }}$ and July $22^{\text {nd }}, 2020$.

Researcher Information

206 For the index researchers in both samples, we used the researcher's Scopus profile to

207 collect the researcher's name, affiliation, geographic region (based on the six World Health

208 Organization [WHO] regions), ${ }^{20} \mathrm{H}$-index, year of first publication, and research field. Research

209 field was collected from the subject area tags listed on the researcher Scopus profile. For each 
210 index researcher, we conducted a Google search of the researcher's name and screened the first

21110 pages to identify an institutional researcher profile. If a researcher profile was available, we

212 also abstracted researcher gender, if clearly indicated in the profile or through identification of

213 gender pronouns, and training (a doctor of medicine (MD), with or without other degrees; a

214 doctor of philosophy $(\mathrm{PhD})$, with or without other degrees (excluding $\mathrm{MD}$ ); or any other

215 degrees).

217 Identification of first and senior author publications in 2019

218 Using the Scopus profile of each index researcher, we identified all of the articles

219 published in 2019 where the index researcher was listed as either the first or senior author.

220 Articles on which the index researcher was a middle author (no matter if 3 authors were listed or

221 20) were excluded, as we assumed the index researcher would not have paid any associated APC

222 as a middle author. For each article, we abstracted the corresponding journal's title and

223 determined whether the article was marked as open access in Scopus. ${ }^{21}$

225 Journal characteristics and article processing charges

226 We used JCR to determine the 2018 journal impact factor for each unique journal. Next,

227 we identified the journal publishing model (open access, hybrid, or subscription-based) and the

228 APCs for each journal. A hybrid journal was defined as a traditional subscription-based journal

229 with a fee-based open access publication option. ${ }^{22}$ To ascertain APCs, we first utilized publisher

230 specific databases, ${ }^{23-37}$ which provide lists of open access and hybrid journals from selected

231 publishers and their associated APCs. If a journal could not be identified through a publisher

232 database, we utilized the Directory of Open Access Journals (DOAJ) ${ }^{11}$ to identify if the journal 
233 was open access. If listed on DOAJ, the journal was considered open access and the

234 corresponding APC was collected from the provided link to the journal website on DOAJ. If the

235 publishing model of a journal could not be determined from those two sources, we relied on the

236 information provided on individual journal websites. Journals without a clear open access policy

237 (either full open access or a hybrid approach) were considered subscription-based.

238 We defined the standard APC for an open access journal as the fee associated with

239 publishing in that journal. For hybrid journals, we defined the APC as the fee associated with

240 optional open access publication. We did not include additional fees not associated with open

241 access publication, such as charges for color printing or reprints, as part of the APCs. If an APC

242 for a given journal was based on word count or page limits, we approximated the standard APC

243 using an average article (3500 words) or page count (8 pages). ${ }^{38}$ In addition to the standard APC,

244 we collected the minimum APC for any journal with multiple APC options. The minimum APC

245 was defined as the lowest APC a researcher could pay given any discounts publicly listed by the

246 journal on the journal website or in the publishing database or different licensing options (e.g.

247 institutional or author membership discounts or commercial versus non-commercial licenses).

249 Statistical Analysis

250 Using descriptive statistics, we characterized the sample of both the general researchers

251 and high-impact researchers, including gender, affiliation, training, geographic region, and

252 seniority (based on H-Index and length of the researcher's career). Length of the researcher's

253 career was approximated by subtracting the year of the index researcher's first publication from

2542020. 
medRxiv preprint doi: https://doi.org/10.1101/2020.12.16.20247643; this version posted December 18, 2020. The copyright holder for this preprint (which was not certified by peer review) is the author/funder, who has granted medRxiv a license to display the preprint in perpetuity.

It is made available under a CC-BY-NC-ND 4.0 International license .

Next, we calculated the median (interquartile range) APCs paid by index researchers in

2562019 for both groups. To do this, for each index researcher, we calculated the maximum total

257 APCs paid in 2019 by assuming that an APC was paid by the index researcher if they were the

258 first or senior author of an article. If an index researcher's article was published in an open

259 access journal with an APC listed, we assumed that the APC was paid without any discounts or

260 waivers. For any of the index researcher's articles published in either hybrid or subscription-

261 based journals, we assumed no APC was paid. Lastly, we also calculated the proportion of

262 articles published in open access journals.

263 We used the Mann Whitney U test or Mood's test as appropriate to compare median

264 APCs paid per index researcher by the characteristics noted above. For comparisons of APCs

265 paid by H-Index and length of the researcher's career, we compared researchers above and below

266 the median H-Index and across quartiles in each sample, respectively. Any unknown values were

267 considered as missing. US dollar amounts were converted to British pound sterling using the

268 average exchange rate for 2019. ${ }^{39}$ All data analyses were conducted in R Version 3.6.1 and used

269 a threshold for statistical significance of 0.05 .

270

271 Sensitivity analyses

272 We repeated the analyses above assuming that index researchers paid: (1) the minimum

273 publicly listed APCs, (2) the APCs for articles published in hybrid journals and classified as

274 "Open Access" on Scopus, (3) APCs for only their first author articles, and (4) APCs for only

275 their senior author articles.

276

277 Part 2: The APC Twitter Whinge Score 
medRxiv preprint doi: https://doi.org/10.1101/2020.12.16.20247643; this version posted December 18, 2020. The copyright holder for this preprint (which was not certified by peer review) is the author/funder, who has granted medRxiv a license to display the preprint in perpetuity.

It is made available under a CC-BY-NC-ND 4.0 International license .

278 To measure the emotional burden that APCs can have on researchers, we also developed and

279 tested a novel metric - the APC Twitter Whinge Score (Box 1). This scoring system uses a highly

280 scientific process to manually screen and evaluate the language used to describe APCs on

281 Twitter. Nine advanced searches were conducted on Twitter to identify Tweets posted between

282 January 1, 2019 and December $31^{\text {st }}, 2019$, containing the phrases "Article cost", "Article costs",

283 "Article fee", "Article processing costs", "Article processing fee", "Article processing charge",

284 "Publication cost", "Publication costs", and "Publication fee". One author (JDW) screened all

285 search results, identified any APC-related Tweets from individual accounts (i.e., excluding

286 Tweets from organizations or journals/publishers advertising their amazingly low APCs), and

287 characterized the tweets using the APC Twitter Whinge Score.

Patient and Public Involvement

This study was an analysis of publicly available, non-clinical data. There was no patient

291 or public involvement in any of the phases of the study, although we expect the public to be

292 broadly supportive of open access publishing since it permits access to information and does not

293 require expensive subscriptions through medical libraries.

295 RESULTS

After accounting for duplicate index researchers and non-English publications, our

297 sample included 241 general and 246 high-impact researchers. Among the 241 general

298 researchers, 239 (99.2\%) had 'Medicine' listed as one of their subject areas on Scopus; all 246

299 high-impact researchers had 'Medicine' listed as one of their subject areas. 
medRxiv preprint doi: https://doi.org/10.1101/2020.12.16.20247643; this version posted December 18, 2020. The copyright holder for this preprint (which was not certified by peer review) is the author/funder, who has granted medRxiv a license to display the preprint in perpetuity.

It is made available under a CC-BY-NC-ND 4.0 International license .

301

302

303

304

305

306

307

308

309

310

311

312

313

314

315

316

317 4, IQR 2 - 8).

318

319

320

321 322 and the International Journal of Molecular Sciences (9/914, 1.0\%). Among the 462 journals with

323 a 2018 JCR impact factor, the median impact factor among their articles was 2.65 (IQR 1.69-

\section{Researcher characteristics}

Nearly all of the general researchers were affiliated with academic centers or hospitals (236/241, 97.9\%); 62 (25.7\%) were based in the Americas, 76 (31.5\%) in Europe, and 69 (28.6\%) in the Western Pacific region (Table 1). An institutional profile could not be identified for approximately one quarter of the researchers $(62 / 241,26.5 \%)$. Among the 179 researchers with an institutional profile, two thirds had an MD (120/179, 67.0\%) and $70(70 / 179,39.1 \%)$ were women. On average, general researchers had published at least two (median: 2, IQR 0 - 4) first or senior author articles in 2019, had an H-Index of 11 (median: 11.0, IQR 3.0 - 23.0), and had at least a 15 -year publication history.

The vast majority of high-impact researchers were affiliated with academic centers or hospitals (213/246, 87.6\%); 85.8\% (211/246) were primarily based in the Americas or Europe (Table 1). An institutional profile was identified for almost all (241/246, 98.0\%) of the highimpact researchers. The majority of those with an institutional profile $(166 / 241,68.9 \%)$ had an MD and one-third $(82 / 241,34.0 \%)$ of the researchers were women. High-impact researchers had, on average, a publication history of greater than 20 years, an H-Index of 38.5 (median: 38.5, IQR 22.0 - 64.0), and had published at least four first or senior author manuscripts in 2019 (median:

\section{Article Characteristics}

In 2019, the 241 general researchers published 914 first or senior author research or review articles in 598 unique journals. The most common journals were Medicine (15/914, 1.6\%) 
medRxiv preprint doi: https://doi.org/10.1101/2020.12.16.20247643; this version posted December 18, 2020. The copyright holder for this preprint (which was not certified by peer review) is the author/funder, who has granted medRxiv a license to display the preprint in perpetuity.

It is made available under a CC-BY-NC-ND 4.0 International license .

324 3.86). The 246 high-impact researchers published 1471 original first or senior author research or

325 review articles in 604 unique journals. The most common journals were New England Journal of

326 Medicine (60/1471, 4.1\%), The Lancet (43/1471, 2.9\%), and PLOS Medicine (36/1471, 2.5\%).

327 Among the 537 journals with a 2018 JCR impact factor, the median impact factor among their

328 articles was 5.05 (IQR 3.18-11.05).

329 Of the 914 first or senior author research or review articles published by the general

330 researchers, $414(414 / 914,45.3 \%)$ were indexed in Scopus as open access. There were 384

331 (41.6\%) articles published in an APC-based journal (Table 2). Of the 457 (457/914, 50.7\%)

332 articles published in journals with a hybrid funding model, $72(72 / 457,15.8 \%)$ were indexed as

333 open access. Among the high-impact researchers, 726 (726/1471, 49.4\%) of the articles were

334 indexed in Scopus as open access. Just under one-third of all articles were published in an APC-

335 based journal $(426 / 1471,28.9 \%)$. Among the $870(870 / 1471,59.1 \%)$ articles published in

336 journals with a hybrid funding model, less than one-third (255/870, 29.3\%) were open access.

338 Article Processing Charges

339 The journal funding model and any associated APCs could be identified for $94.1 \%$

340 (860/914) of the first or senior research or review articles published by the general researchers

341 and $97.8 \%(1439 / 1471)$ of the articles published by the high-impact researchers. In 2019, the 241

342 general and 246 high-impact researchers paid an estimated total of \$497716 (£390209) and

$343 \$ 1067869$ (£837209) in APCs, respectively, for their first and senior author articles. Although

344 the median APCs paid by general clinical medical researchers was $\$ 191$ (IQR $\$ 0$ - \$2500) [£150,

$345 £ 0$ - £1960], one researcher was estimated as having paid \$30115 (£23610) in APCs (Table 3,

346 Figure 2). The median total APCs per researcher in the high-impact sample was $\$ 2900$ (IQR $\$ 0$ 
medRxiv preprint doi: https://doi.org/10.1101/2020.12.16.20247643; this version posted December $18,2020$. The copyright holder for this preprint (which was not certified by peer review) is the author/funder, who has granted medRxiv a license to display the preprint in perpetuity.

It is made available under a CC-BY-NC-ND 4.0 International license .

347 - \$5465) [£2274, £0 - £4285]; one researcher was estimated as having paid as much as \$34676

348 (£27186) in APCs.

349 In sensitivity analyses, after including potential discounts on standard APCs, the

350 minimum listed APCs general researchers could have paid for their first and senior author

351 publications in 2019 was $\$ 0$ (IQR: \$0 - \$2500) [£0, £0 - £1960] (Table 3). However, researchers

352 in the high-impact sample would have paid approximately $\$ 300$ less on average (median: $\$ 2600$,

353 IQR \$0 - \$5465) [£2038, £0 - £4285]. If all researchers paid the APCs for their first and senior

354 open access published in hybrid journals (as opposed to the articles being made available through

355 delayed open access due to funder requirements, at the discretion of the journal, or through other

356 mechanisms such as self-archiving) the median total APCs paid by the general and high-impact

357 researchers would have been \$739 (IQR \$0 - \$3950) [£579, £0-£3097] and \$5000 (IQR \$0 -

358 \$10879) [£3920,£0-£8529], respectively.

359 The estimated median total APCs paid did not vary across index researcher gender,

360 training, H-index, and years since first publication (Table 4). However, high-impact researchers

361 in the Region of the Americas did have lower median total APCs per researcher than those in

362 other regions of the world (Region of the Americas: \$1695, IQR \$0-\$3935 [£1329, £0 - £3085]

363 vs. Other regions: \$4800, IQR \$1888-\$8290 [£3763, £1480 - £6500]; p <0.001).

The APC Twitter Whinge Score

366 Among the sample of 195 APC-related tweets posted by individuals in 2019, the majority

$367(118 / 195,60.5 \%)$ were classified as publicly resentful of APCs (Figure 3). There were two

$368(2 / 203,1.0 \%)$ additional tweets that described APCs using sweary language (although, we can

369 only assume that the authors meant "Why The Fee!?" when they wrote WTF). 
medRxiv preprint doi: https://doi.org/10.1101/2020.12.16.20247643; this version posted December 18, 2020. The copyright holder for this preprint (which was not certified by peer review) is the author/funder, who has granted medRxiv a license to display the preprint in perpetuity.

It is made available under a CC-BY-NC-ND 4.0 International license .

370

371

372

373

374

375

376

377

378

379

380

381

382

383

384 385 APCs.

386

387

388

389

390

391

392

\section{DISCUSSION}

In this cross-sectional study, 241 and 246 randomly selected general and high-impact medical researchers published a median of 2 and 4 first or senior author research or review articles in 2019, respectively. Approximately one-third of the articles across both samples were published in journals that required an APC. The median total APCs per general and high-impact researcher in 2019 was $\$ 191$ [ $£ 150$ ] and \$2900 [£2274], respectively, with one researcher who may have incurred as much as $\$ 34676$ in APCs [£27186]. Across both samples, there were no meaningful differences in APCs paid by gender, affiliation, or training. However, in the highimpact sample, researchers from the Region of the Americas had a lower median total APCs paid (\$1695) [£1329] than researchers from all other regions (\$4800) [£3763]. As open access publishing with APCs becomes increasingly common, it is important to consider the financial (and emotional) implications for individual researchers across different fields, settings, and levels of seniority. Otherwise, we risk creating a pay-to-publish system that favors wellresourced authors from well-resourced institutions and areas of the world. Without a solution that works for all stakeholders, we fear that Twitter will become over-run with tweets whinging about

Our study suggests that many general and high-impact researchers could have paid thousands of dollars in APCs to publish their first and senior research and review articles in 2019. Across the 487 index researchers in both samples, which represents only a fraction of all biomedical researchers actively publishing in 2019, the total estimated APCs was approximately $\$ 1500000$ [£1176000]. Given that general researchers published a median of 2 first or senior articles per year (potentially in lower impact factor journals with smaller APCs) ${ }^{40,41}$ it may not be surprising that the median total APCs per researcher was relatively low (\$191) [£150]. However, 
393 among high-impact researchers, who published a median of 4 first or senior research or review

394 articles in 2019, the median total APCs per researcher was \$2900 [£2274]. This suggests that

395 these researchers paid an APC for one of every four of their first or senior author articles.

396 Moreover, if we extrapolate our findings, individual researchers could spend a total of $\$ 116000$

397 [£90944] on publication costs over a 40-year career.

The rise of the APC-centered open access publishing model poses a number of serious

399 challenges for researchers. ${ }^{18,42}$ Approximately one-third of the first or senior research and review

400 articles published by the general and high-impact researchers were published in an open access

401 journal that required an APC. Although not all open access journals charge APCs, approximately

$40250 \%$ of all articles that are published open access are published in journals that do. ${ }^{43}$ When grant

403 money or institutional discretionary funds are used to cover APCs, as is the case for

404 approximately $80 \%$ researchers in the health, biological, and life sciences, ${ }^{10}$ fewer resources are

405 available for other research-related expenses. ${ }^{42}$ For instance, the $\$ 2900$ [£2274] median amount

406 spent by researchers in our high-impact sample could support the attendance of multiple

407 individuals at a conference or a critical piece of research equipment (or a number of other radical

408 publication options outlined in Figure 2). Moreover, for researchers spending tens of thousands

409 of dollars a year on APCs, these funds could have covered the tuition of a graduate student or the

410 partial salary of a postdoctoral fellow. Second, the amount of APCs has risen dramatically in

411 recent years - at a rate nearly three times that of the expected inflation rate. ${ }^{13,44}$ These increases

412 have raised questions about whether APCs actually reflect the cost of publishing or if publishers

413 are driven by primarily financial motives. ${ }^{9,42}$ While there does not appear to be a quality

414 difference between subscription-based and open access journals, ${ }^{5,45}$ there is some evidence that

415 journals with higher APCs are perceived to be higher impact. ${ }^{41,45}$ 
Lastly, the amount of APCs can be prohibitive to many researchers, either based on

417 field ${ }^{10}$, seniority ${ }^{14}$, disparities in research funding ${ }^{15,16}$, or setting. ${ }^{18,42,46}$ For instance, evidence

418 suggests that researchers from countries with gross domestic products (GDP) lower than $\$ 25000$

419 [£19600] are more likely to pay APCs out of personal funds compared to researchers from

420 countries with GDPs higher than $\$ 25000$ [£19600]. ${ }^{10}$ It is important to note that certain journals

421 grant fee waivers to researchers from low- and middle-income countries or to researchers

422 without funding to support publication. However, many researchers may be unaware of the

423 specific journals that do provide waivers. ${ }^{17}$ Furthermore, journal waivers do not necessarily

424 address all of the inequities imposed by APCs. For early career researchers (i.e. the first, second,

425 third, and senior authors on this manuscript!), with no established grant funding or accumulated

426 discretionary funds (i.e., the first, second, third, and senior authors on this manuscript!), even

427 discounted APCs can be prohibitive.

428 As open access publishing becomes the norm, numerous opportunities exist to address

429 the disadvantages that may prevent many researchers from paying for APCs. At the journal level,

430 increased transparency may be necessary to inform researchers from low- and middle-income

431 countries or at early stages of their careers about the waivers that are available. It is also critical

432 that funders and institutions leverage their influence to restrain the hyperinflation of APCs. In

433 2018, cOAlition S, an international consortium of research funders, launched 'Plan S'. This

434 initiative, which aims to make all scientific publications resulting from publicly-funded research

435 immediately available open access ${ }^{47}$, has proposed an APC fee cap. ${ }^{44,47}$ As more scientific

436 research is available open access, institutions can shift resources from subscriptions to a pool of

437 funds to support the expenses for early career researchers. Among universities in the United

438 Kingdom, there is an ongoing commitment to promoting open access publishing by encouraging 
439 submission to open access repositories and by assisting researchers in the payment of APCs for

440 immediate open access publication. ${ }^{13}$ At the funder level, more agencies could embrace the

441 Gates Foundation or the Charity Open Access Fund model utilized by the Wellcome Trust,

442 where researchers supported by these funders can request coverage of any associated APCs. ${ }^{48,49}$

443 Individual researchers can also increasingly choose to release their research open access through

444 venues such as pre-print servers, like medRxiv, without undermining their ability to publish their

445 findings in peer-reviewed journals. ${ }^{50}$ Furthermore, so-called "Green Open Access" policies,

446 where researchers can elect to post peer-reviewed papers in open access repositories, are

447 available for many journals, although most researchers do not utilize this option. ${ }^{51-53}$

448 It is important to note that limiting the amount of science that exists behind a paywall can

449 also have clear advantages for individual researchers and the public. ${ }^{43,54}$ Open access publishing

450 can enhance equity by improving the ability of researchers, either working in low-resource

451 settings or at institutions that cannot support the hefty cost of journal subscriptions, to access

452 publications. ${ }^{52,55}$ Articles published open-access can receive a citation boost compared to those

453 behind paywalls, a boon for researchers looking to increase the audience and impact of their

454 work. ${ }^{56}$ Furthermore, APCs often serve an important purpose in the publication process. APCs

455 can be used to pay the salaries of journal editors, who are often responsible for screening a large

456 number of manuscript submissions, identifying and soliciting appropriate peer-reviewers (and

457 performing their own peer-review), and helping improve the quality of studies as they transition

458 from submission to eventual publication. Moreover, APCs could be used to pay peer reviewers

459 for their efforts - a service currently provided by researchers for free even in cases where

460 researchers are paying thousands of dollars to publish an article. ${ }^{57}$ However, if APCs continue to

461 increase, questions will continue to be raised about journals' potential profit motives, predatory 
medRxiv preprint doi: https://doi.org/10.1101/2020.12.16.20247643; this version posted December 18, 2020. The copyright holder for this preprint (which was not certified by peer review) is the author/funder, who has granted medRxiv a license to display the preprint in perpetuity.

It is made available under a CC-BY-NC-ND 4.0 International license .

462 journals, and hybrid journals that receive payments from both institutions and researchers (we

463 refer to this as 'double-dipping'). Scientific publishing is changing and it will be necessary for all

464 stakeholders to adapt.

465

466

Limitations of this study

467 This study is subject to certain limitations. First, we apologize for some of the

468 nomenclature used in our manuscript (i.e., "general medical researchers" and "high-impact

469 medical researchers"). We recognize the limitations of focusing on journal impact factors, and do

470 not believe that authors should be classified as "general" or "high-impact" based upon one senior

471 author research or review article published in one of the ten highest impact factor medical

472 journals. Perhaps, we should have classified authors as having "good" or "bad" H-indices or

473 Altmetric Attention Scores, since there seems to be universal agreement about the calculation

474 and use of those metrics.

475 Second, our estimates do not represent the actual APCs that the index researchers in our

476 sample paid. Without access to the financial records from the index researchers and journals in

477 our sample, we had to make several assumptions about the nature of APC payments, most

478 fundamentally that it was the index author who paid the APCs, rather than a funder or other

479 organization. In particular, articles for which the index researcher was a middle author were

480 excluded, as we assumed index researchers are less likely to pay associated APCs as a middle

481 author. We also did not account for situations in which APCs may have been paid by co-primary

482 or co-senior authors. Additionally, we used the most recent APCs listed on journal website,

483 which may not represent the APCs paid in 2019. For our primary analysis, we assumed that

484 researchers in our sample did not pay the optional APCs for open access publications in hybrid 
485 journals. Using publicly available information, it is difficult to determine if open access

486 publications in hybrid journals were paid for by researchers or were available open access due to

487 funder requirements or journal discretion. Furthermore, we did not account for any unlisted

488 discounts or fee waivers provided by journals to researcher institutions in our analyses. Although

489 the true minimum APCs per researcher may be lower than our estimate, our results did not

490 change substantially when analyses were repeated using the lowest APCs listed by journals

491 (excluding waivers). Overall, our sensitivity analyses provide a range of what researchers are

492 likely to have paid.

493 Third, although Scopus provides a comprehensive accounting of a given researcher's

494 publication history, not all manuscripts published by a researcher may be indexed on Scopus.

495 Furthermore, Scopus may create multiple researcher profiles for the same researcher, due to

496 changing institutions or different permutations of the researcher's name. However, we attempted

497 to identify and include all researcher profiles for each index researcher. Second, we relied on

498 articles classified as 'articles' or 'reviews' on Scopus. Although this method allowed us to

499 objectively screen and classify index researcher articles, it is possible that we may have included

500 or excluded articles that were incorrectly classified by Scopus.

$502 \quad$ Life is no picnic

503 To draw on the picnic analogy mentioned above, the model of open access publication

504 with APCs clearly has great advantages for picnic eaters - who get free food - and for picnic site

505 owners, who can set the charges for food provision. Researchers, however, are left with the effort

506 and cost of growing the food and bringing it to the picnic site. They must then wait for it to be

507 inspected by a team of (usually unpaid) food tasters and be willing to respond to any disparaging 
medRxiv preprint doi: https://doi.org/10.1101/2020.12.16.20247643; this version posted December 18, 2020. The copyright holder for this preprint (which was not certified by peer review) is the author/funder, who has granted medRxiv a license to display the preprint in perpetuity.

It is made available under a CC-BY-NC-ND 4.0 International license .

508 comments that these reviewers think fit to make. If they are then allowed on to the picnic site,

509 they are then charged for the privilege of laying out their meal for the public.

510 Our Twitter analysis provides evidence that this process can take its toll on all but the

511 saintliest contributors. We found that a significant number are driven to exceed the bounds of

512 polite professional discourse. This leads us to postulate that beneath the obvious advantages of

513 open access publication there may lie hidden moral and financial harms to contributors. These

514 could include arguments with colleagues at work, financial arguments with spouses who are

515 unable to appreciate the subtleties of the APC system, sleep disturbance, and even the possible

516 use of alcohol before tweeting.

\section{Conclusion}

519 This cross-sectional analysis suggests that clinical medical researchers paid as much as

$520 \$ 34676[£ 27186]$ in total APCs for their first and senior author research and review articles in

521 2019. As journals with APCs become more common, it is important to understand the cost to

522 researchers, especially those who may not have the funding or institutional resources to cover

523 these costs. If we do not address rising publication costs, we risk creating a pay-to-publish

524 system that favors well-resourced authors from well-resources institutions and areas of the

525 world. Furthermore, researchers may increasingly turn to Twitter to complain about the financial

526 costs of publishing, and demand compensation for peer-reviewing articles. 
medRxiv preprint doi: https://doi.org/10.1101/2020.12.16.20247643; this version posted December 18, 2020. The copyright holder for this preprint (which was not certified by peer review) is the author/funder, who has granted medRxiv a license to display the preprint in perpetuity.

It is made available under a CC-BY-NC-ND 4.0 International license .

\section{ACKNOWLEDGEMENTS}

532 Contributors: JDW and JSR first conceived the study idea when arguing about who would have

533 to pay the APC for one of their previous manuscripts. MKE, KN, JSR, and JDW designed this

534 study. MKE, XS, and JJS acquired the author, journal, and APC data. JDW contributed to data

535 collection by spending a full day searching and browsing Twitter (a normal day at the office).

536 MKE conducted the statistical analysis. MKE, JSR, and JDW drafted the manuscript. All authors

537 participated in the interpretation of the data and critically revised the manuscript for important

538 intellectual content, not that there is anything all that important here. MKE and JDW had full

539 access to all the data in the study and take responsibility for the integrity of the data and the

540 accuracy of the data analysis. MKE and JDW are guarantors. JDW provided supervision, and

541 despite being the senior author, begged JSR to pay the APCs.

542 Funding: None. Therefore, the APC for this manuscript will come from JDW's discretionary

543 piggy bank. The authors assume full responsibility for the accuracy and completeness of the

544 ideas presented.

545 Competing interests: All authors have completed the ICMJE uniform disclosure form

546 at www.icmje.org/coi disclosure.pdf and declare: In the past 36 months, XS received a

547 scholarship from China Scholarship Council. KN thinks the estimated APCs are peanuts in

548 comparison to the millions of dollars her employer spends on journal subscriptions, and wonders

549 why authors who avoid APC-induced apoplexy by publishing in subscription journals so

550 infrequently self-archive their papers. RL discloses that he is an avid fan of picnics. JSR is a

551 former Associate Editor of JAMA Internal Medicine, a current Research Editor at BMJ, pays

552 thousands of dollars annually in APCs, and has received research support through Yale from

553 Johnson and Johnson to develop methods of clinical trial data sharing, from the FDA to establish 
medRxiv preprint doi: https://doi.org/10.1101/2020.12.16.20247643; this version posted December 18, 2020. The copyright holder for this preprint (which was not certified by peer review) is the author/funder, who has granted medRxiv a license to display the preprint in perpetuity.

It is made available under a CC-BY-NC-ND 4.0 International license .

554 a Center for Excellence in Regulatory Science and Innovation (CERSI) at Yale University and

555 the Mayo Clinic (U01FD005938), from the Medical Device Innovation Consortium as part of the

556 National Evaluation System for Health Technology (NEST), from the Agency for Healthcare

557 Research and Quality (R01HS022882), from the National Heart, Lung and Blood Institute of the

558 National Institutes of Health (NIH) (R01HS025164, R01HL144644), and from the Laura and

559 John Arnold Foundation. JDW received research support through the Collaboration for Research

560 Integrity and Transparency from the Laura and John Arnold Foundation and through the Center

561 for Excellence in Regulatory Science and Innovation (CERSI) at Yale University and the Mayo

562 Clinic (U01FD005938).

563 Patient consent: Not required

564 Ethical approval: Not required

565 Data sharing: The dataset will be made available via a publicly accessible repository on

566 publication:

567 Transparency: The lead author (manuscripts guarantor) (JDW) affirms that this manuscript is

568 an honest, accurate, and transparent account of the study being reported; that no important

569 aspects of the study have been omitted; and that any discrepancies from the study as planned

570 (and, if relevant registered) have been explained.

571 License: The Corresponding Author has the right to grant on behalf of all authors and does grant

572 on behalf of all authors, a worldwide license to the Publishers and its licensees in perpetuity, in

573 all forms, formats and median (whether known now or created in the future), to i) publish,

574 reproduce, distribute, display and store the Contribution, ii) translate the Contribution into other

575 languages, create adaptations, reprints, include within collections and create summaries, extracts

576 and/or, abstracts of the Contribution, iii) create any other derivative work(s) based on the 
medRxiv preprint doi: https://doi.org/10.1101/2020.12.16.20247643; this version posted December 18, 2020. The copyright holder for this preprint (which was not certified by peer review) is the author/funder, who has granted medRxiv a license to display the preprint in perpetuity. It is made available under a CC-BY-NC-ND 4.0 International license.

577 Contribution, iv) to exploit all subsidiary rights in the Contribution, v) the inclusion of electronic 578 links from the Contribution to third party material where-ever it may be located; and, vi) license 579 any third party to do any or all of the above. The default license, a CC BY NC license, is needed.

580 This is an Open Access article distributed in accordance with the Creative Commons Attribution

581 Non Commercial (CC BY-NC 4.0) license, which permits others to distribute, remix, adapt,

582 build upon this work non-commercially, and license their derivative works on different terms,

583 provided the original work is properly cited and the use is non-commercial.

584 See: http://creativecommons.org/licenses/by-nc/4.0/. 
medRxiv preprint doi: https://doi.org/10.1101/2020.12.16.20247643; this version posted December 18, 2020. The copyright holder for this preprint (which was not certified by peer review) is the author/funder, who has granted medRxiv a license to display the preprint in perpetuity.

It is made available under a CC-BY-NC-ND 4.0 International license .

1. Ioannidis JPA, Boyack KW, Klavans R. Estimates of the Continuously Publishing Core in the Scientific Workforce. Amaral LANunes, ed. PLOS ONE. 2014;9(7):e101698. doi:10.1371/journal.pone.0101698

2. UNESCO. UNESCO science report: towards 2030. Published online 2015.

3. Rice DB, Raffoul H, loannidis JPA, Moher D. Academic criteria for promotion and tenure in biomedical sciences faculties: cross sectional analysis of international sample of universities. BMJ. Published online June 25, 2020:m2081. doi:10.1136/bmj.m2081

4. NSF. Publication Output: U.S. Trends and International Comparisons. Published online 2019.

5. Björk B-C, Solomon D. Open access versus subscription journals: a comparison of scientific impact. BMC Med. 2012;10(1):73. doi:10.1186/1741-7015-10-73

6. Munafò MR, Nosek BA, Bishop DVM, et al. A manifesto for reproducible science. Nat Hum Behav. 2017;1(1):0021. doi:10.1038/s41562-016-0021

7. Resnick B. The war to free science. Vox. Published June 3, 2019. Accessed July 15, 2020. https://www.vox.com/the-highlight/2019/6/3/18271538/open-access-elsevier-californiasci-hub-academic-paywalls

8. Romaine SB Barbara Albee, \& Sion. Deal or No Deal | Periodicals Price Survey 2019. Library Journal. Accessed July 23, 2020. https://www.libraryjournal.com?detailStory=Deal-or-NoDeal-Periodicals-Price-Survey-2019

9. Noorden RV. THE TRUE COST OF SCIENCE PUBLISHING. Nature. 2013;495:426-429.

10. Solomon DJ, Björk B-C. Publication fees in open access publishing: Sources of funding and factors influencing choice of journal. J Am Soc Inf Sci Technol. 2012;63(1):98-107. doi:10.1002/asi.21660

11. Directory of Open Access Journals. Directory of Open Access Journals. Accessed February 17, 2020. https://www.doaj.org/about

12. Dallmeier-Tiessen S, Darby R, Goerner B, et al. Highlights from the SOAP project survey. What Scientists Think about Open Access Publishing. ArXiv11015260 Cs. Published online January 28, 2011. Accessed July 15, 2020. http://arxiv.org/abs/1101.5260

614

13. Universities UK. Monitoring the Transition to Open Access: December 2017. Universities UK; $: 52$. 
medRxiv preprint doi: https://doi.org/10.1101/2020.12.16.20247643; this version posted December 18, 2020. The copyright holder for this preprint (which was not certified by peer review) is the author/funder, who has granted medRxiv a license to display the preprint in perpetuity.

It is made available under a CC-BY-NC-ND 4.0 International license .

615

616

617

618

619

620

621

622

623

624

625

626

627

628

629

630

631

632

633

634

635

636

637

638

639

640

641

642

643

644

645

646

647

14. Nicholas D, Rodríguez-Bravo B, Watkinson A, et al. Early career researchers and their publishing and authorship practices: ECRs publishing and authorship practices. Learn Publ. 2017;30(3):205-217. doi:10.1002/leap.1102

15. Ginther DK, Schaffer WT, Schnell J, et al. Race, Ethnicity, and NIH Research Awards. Science. 2011;333(6045):1015-1019. doi:10.1126/science.1196783

16. Hoppe TA, Litovitz A, Willis KA, et al. Topic choice contributes to the lower rate of NIH awards to African-American/black scientists. Sci Adv. 2019;5(10):eaaw7238. doi:10.1126/sciadv.aaw7238

17. Lawson S. Fee Waivers for Open Access Journals. Publications. 2015;3(3):155-167. doi:10.3390/publications3030155

18. Peterson A, Emmett A, Greenberg M. Open Access and the Author-Pays Problem: Assuring Access for Readers and Authors in the Global Academic Community. J Librariansh Sch Commun. 2013;1(3):eP1064. doi:10.7710/2162-3309.1064

19. InCites Journal Citation Reports. Accessed June 16, 2020. https://jcr.clarivate.com/JCRLandingPageAction.action?Init=Yes\&SrcApp=IC2LS\&SID=H2BzzoBH7fllbTAafOrld9xxFix2F5DwRnQm618×2dSruBm8K4GbN6ZPQtUZbfUAx3Dx3DADCSreBC9mJb3O7KgOE12w×3Dx3DqBgNuLRjcgZrPm66fhjx2Fmw×3Dx3D-h9tQNJ9Nv4eh45yLvkdX3g×3Dx3D

20. World Health Organization. WHO Regional Offices. Accessed April 20, 2020. https://www.who.int/about/who-we-are/regional-offices

21. Elsevier. Elsevier/Impactstory agreement will make open access articles easier to find on Scopus. Elsevier Connect. Accessed July 15, 2020. https://www.elsevier.com/connect/elsevier-impactstory-agreement-will-make-openaccess-articles-easier-to-find-on-scopus

22. Laakso M, Björk B-C. Hybrid open access-A longitudinal study. J Informetr. 2016;10(4):919932. doi:10.1016/j.joi.2016.08.002

23. Article Processing Charges | Wolters-Kluwer. Accessed July 20, 2020. https://wkauthorservices.editage.com/open-access/hybrid.html

24. Article Processing Charges | Oxford. Oxford Academic. Accessed July 20, 2020. https://academic.oup.com/journals/pages/ita-journals-a-to-z

25. Article Processing Charges | Karger. Accessed July 20, 2020. https://www.karger.com/Journal/Index?oa=true\&sub=true\&dis=false\&s=acta\%20cytologi ca\&ss $=\& \max =5 \&$ skip=0\&open=null\&closeSF=null 
medRxiv preprint doi: https://doi.org/10.1101/2020.12.16.20247643; this version posted December 18, 2020. The copyright holder for this preprint (which was not certified by peer review) is the author/funder, who has granted medRxiv a license to display the preprint in perpetuity.

It is made available under a CC-BY-NC-ND 4.0 International license .

648

26. Article Processing Charges | Taylor \& Francis Online. Accessed July 20, 2020. https://www.tandfonline.com/openaccess/openjournals

27. Article Processing Charges | SAGE Publications Ltd. Accessed July 20, 2020. https://uk.sagepub.com/en-gb/eur/pure-gold-open-access-journals-at-sage

28. Article Processing Charges | Future Medicine. Accessed July 20, 2020. https://www.futuremedicine.com/authorguide/openaccess

29. Article Processing Charges | Hindawi. Hindawi. Accessed July 20, 2020. https://www.hindawi.com/publish-research/authors/article-processing-charges/

30. Article Processing Charges | MAG Online Library. Accessed July 20, 2020. https://www.magonlinelibrary.com/page/authors/openaccess

31. Article Processing Charges | MDPI. Accessed July 20, 2020. https://www.mdpi.com/apc\#Journal_Specific_APCs

32. Article Processing Charges | Thieme Open. Accessed July 20, 2020. https://open.thieme.com/web/19/apcs

33. Article Processing Charges | Emerald Publishing. Accessed July 20, 2020. https://www.emeraldgrouppublishing.com/services/authors/publish-us/publish-openaccess/journal\#apc-charges

34. Article Processing Charges | JMIR. Accessed July 20, 2020. https://www.jmir.org

35. Article Processing Charges | Springer. www.springer.com. Accessed July 20, 2020. https://www.springer.com/gp/open-access/springer-open-choice

36. Article Processing Charges | Elsevier. Accessed July 20, 2020. https://www.elsevier.com/about/policies/pricing

37. Article Processing Charges | SAGE Open. SAGE Publications Ltd. Published October 6, 2015. Accessed July 20, 2020. https://uk.sagepub.com/en-gb/eur/sage-choice-journal-andpricing-exceptions

38. Falagas ME, Zarkali A, Karageorgopoulos DE, Bardakas V, Mavros MN. The Impact of Article Length on the Number of Future Citations: A Bibliometric Analysis of General Medicine Journals. Fortunato S, ed. PLOS ONE. 2013;8(2):e49476. doi:10.1371/journal.pone.0049476

39. Yearly Average Currency Exchange Rates | Internal Revenue Service. Accessed July 23, 2020. https://www.irs.gov/individuals/international-taxpayers/yearly-average-currencyexchange-rates 
medRxiv preprint doi: https://doi.org/10.1101/2020.12.16.20247643; this version posted December 18, 2020. The copyright holder for this preprint (which was not certified by peer review) is the author/funder, who has granted medRxiv a license to display the preprint in perpetuity.

It is made available under a CC-BY-NC-ND 4.0 International license .

679

680

681

682

683

684

685

686

687

688

689

690

691

692

693

694

695

696

697

698

699

700

701

702

703

704

705

706

707

708

709

710

711

40. Shamseer L, Moher D, Maduekwe O, et al. Potential predatory and legitimate biomedical journals: can you tell the difference? A cross-sectional comparison. BMC Med. 2017;15(1):28. doi:10.1186/s12916-017-0785-9

41. Björk B-C, Solomon D. Article processing charges in OA journals: relationship between price and quality. Scientometrics. 2015;103(2):373-385. doi:10.1007/s11192-015-1556-z

42. Shaw DM, Elger BS. Unethical Aspects of Open Access. Account Res. 2018;25(7-8):409-416. doi:10.1080/08989621.2018.1537789

43. Laakso M, Björk B-C. Anatomy of open access publishing: a study of longitudinal development and internal structure. BMC Med. 2012;10(1):124. doi:10.1186/1741-701510-124

44. Khoo SY-S. Article Processing Charge Hyperinflation and Price Insensitivity: An Open Access Sequel to the Serials Crisis. Liber Q. 2019;29(1):1. doi:10.18352/lq.10280

45. Pollock D, Michael A. Open access mythbusting: Testing two prevailing assumptions about the effects of open access adoption. Learn Publ. 2019;32(1):7-12. doi:10.1002/leap.1209

46. Shieber SM. Equity for Open-Access Journal Publishing. PLOS Biol. 2009;7(8):e1000165. doi:10.1371/journal.pbio.1000165

47. "Plan S" and "cOAlition S" - Accelerating the transition to full and immediate Open Access to scientific publications. Accessed July 15, 2020. https://www.coalition-s.org/

48. Baptista D. Charity Open Access Fund (COAF) open access spend and compliance monitoring: 2017-18. Published online 2019:2664082 Bytes. doi:10.6084/M9.FIGSHARE.8010617

49. Open Access Policy. Published January 1, 1AD. Accessed July 15, 2020. https://www.gatesfoundation.org/How-We-Work/General-Information/Open-AccessPolicy

50. Massey DS, Opare MA, Wallach JD, Ross JS, Krumholz HM. Assessment of Preprint Policies of Top-Ranked Clinical Journals. JAMA Netw Open. 2020;3(7):e2011127-e2011127. doi:10.1001/jamanetworkopen.2020.11127

51. Baffy G, Burns MM, Hoffmann B, et al. Scientific Authors in a Changing World of Scholarly Communication: What Does the Future Hold? Am J Med. 2020;133(1):26-31. doi:10.1016/j.amjmed.2019.07.028

52. Smith E, Haustein S, Mongeon P, Shu F, Ridde V, Larivière V. Knowledge sharing in global health research - the impact, uptake and cost of open access to scholarly literature. Health Res Policy Syst. 2017;15. doi:10.1186/s12961-017-0235-3 
medRxiv preprint doi: https://doi.org/10.1101/2020.12.16.20247643; this version posted December 18, 2020. The copyright holder for this preprint (which was not certified by peer review) is the author/funder, who has granted medRxiv a license to display the preprint in perpetuity.

It is made available under a CC-BY-NC-ND 4.0 International license .

712 53. Button OA. Open Access Button. Accessed July 23, 2020. https://openaccessbutton.org

713 54. Cuschieri S. WASP: Is open access publishing the way forward? A review of the different

714 ways in which research papers can be published. Early Hum Dev. 2018;121:54-57.

715 doi:10.1016/j.earlhumdev.2018.02.017

716 55. Chan L, Kirsop B, Arunachalam S. Towards Open and Equitable Access to Research and

717 Knowledge for Development. PLOS Med. 2011;8(3):e1001016.

719 56. The Open Access Citation Advantage Service (OACA). SPARC Europe. Accessed July 15, 2020.

720

721 https://sparceurope.org/what-we-do/open-access/sparc-europe-open-access-

722 57. Diamandis EP. Peer review as a business transaction. Nature. 2015;517(7533):145-145.

723 doi:10.1038/517145a

724 
medRxiv preprint doi: https://doi.org/10.1101/2020.12.16.20247643; this version posted December 18, 2020. The copyright holder for this preprint (which was not certified by peer review) is the author/funder, who has granted medRxiv a license to display the preprint in perpetuity. It is made available under a CC-BY-NC-ND 4.0 International license .

\section{FIGURE LEGENDS}

726 Figure 1. A visualization of the sampling and data abstraction approach

727 Figure 2. Distribution of research spending on article processing charges in 2019

728 Figure 3. The Article Processing Charge-Related Twitter Whinge Score 
medRxiv preprint doi: https://doi.org/10.1101/2020.12.16.20247643; this version posted December 18, 2020. The copyright holder for this preprint (which was not certified by peer review) is the author/funder, who has granted medRxiv a license to display the preprint in perpetuity.

It is made available under a CC-BY-NC-ND 4.0 International license .

729

\begin{tabular}{|l|l|}
\hline Box 1. The Article Processing Charge Twitter Whinge Score (C TM $~$ & Tweets praising or defending article processing costs \\
\hline Publicly grateful & $\begin{array}{l}\text { Tweets that note article processing costs, but neither tip their hand } \\
\text { toward positive or negative; factual statements }\end{array}$ \\
\hline Calmly resigned & $\begin{array}{l}\text { Tweets containing strong or sarcastic language, expressing concern, } \\
\text { anger, or regret towards article processing costs (bonus points: emoji's } \\
\text { and GIFs) }\end{array}$ \\
\hline Publicly opposed & $\begin{array}{l}\text { Tweets containing sweary language, not suitable for publication in a } \\
\text { journal }\end{array}$ \\
\hline
\end{tabular}


medRxiv preprint doi: https://doi.org/10.1101/2020.12.16.20247643; this version posted December 18, 2020. The copyright holder for this preprint (which was not certified by peer review) is the author/funder, who has granted medRxiv a license to display the preprint in perpetuity.

It is made available under a CC-BY-NC-ND 4.0 International license .

Table 1. Characteristics of general and high-impact medical researchers

\begin{tabular}{|c|c|c|}
\hline & $\begin{array}{l}\text { General researchers } \\
\qquad(\mathbf{N}=\mathbf{2 4 1})\end{array}$ & $\begin{array}{l}\text { High-Impact } \\
\text { researchers } \\
(\mathbf{N}=\mathbf{2 4 6})\end{array}$ \\
\hline & \multicolumn{2}{|c|}{ No. $(\%)$} \\
\hline \multicolumn{3}{|l|}{ Gender } \\
\hline Male & $109(45.2)$ & $159(64.6)$ \\
\hline Female & $70(29.1)$ & $82(33.3)$ \\
\hline Unknown/Unavailable $^{a}$ & $62(25.7)$ & $5(2.0)$ \\
\hline \multicolumn{3}{|l|}{ Affiliation } \\
\hline Academia/Hospital & $236(97.9)$ & $213(86.6)$ \\
\hline Government & $3(1.2)$ & $10(4.1)$ \\
\hline Non-governmental or non-profit & $1(0.4)$ & $12(4.9)$ \\
\hline Industry & $1(0.4)$ & $7(2.9)$ \\
\hline Other & $0(0.0)$ & $2(0.8)$ \\
\hline Unknown/Unavailable & $0(0.0)$ & $2(0.8)$ \\
\hline \multicolumn{3}{|l|}{ Training ${ }^{b}$} \\
\hline MD & $120(49.8)$ & $166(67.5)$ \\
\hline $\mathrm{PhD}$ only & $58(24.1)$ & $61(24.8)$ \\
\hline Other degree only & $3(1.2)$ & $5(2.0)$ \\
\hline Unknown/Unavailable & $60(24.9)$ & $14(5.7)$ \\
\hline \multicolumn{3}{|l|}{ Region } \\
\hline African Region & $3(1.2)$ & $4(1.6)$ \\
\hline Region of the Americas & $62(25.7)$ & $144(58.5)$ \\
\hline South-East Asia Region & $13(5.4)$ & $1(0.4)$ \\
\hline European Region & $76(31.5)$ & $67(27.2)$ \\
\hline Eastern Mediterranean Region & $18(7.5)$ & $4(1.6)$ \\
\hline Western Pacific Region & 69 (28.6) & $25(10.2)$ \\
\hline Unknown/Unavailable & $0(0.0)$ & $1(0.4)$ \\
\hline H-Index, median (IQR) & $11.0(3.0,23.0)$ & $38.5(22.0,64.0)$ \\
\hline Years since first publication, median (IQR) & $15.0(7.0,25.0)$ & $22.5(14.3,32.0)$ \\
\hline \multicolumn{3}{|l|}{ Number of articles per author, median (IQR) } \\
\hline First and senior author articles & $2(1,5)$ & $4(2,8)$ \\
\hline Senior author articles only & $2(1,4)$ & $4(2,8)$ \\
\hline First author articles only & $0(0,1)$ & $0(0,1)$ \\
\hline Corresponding author articles (first or senior) & $1(0,2)$ & $2(0,4)$ \\
\hline
\end{tabular}


medRxiv preprint doi: https://doi.org/10.1101/2020.12.16.20247643; this version posted December 18, 2020. The copyright holder for this preprint (which was not certified by peer review) is the author/funder, who has granted medRxiv a license to display the preprint in perpetuity.

It is made available under a CC-BY-NC-ND 4.0 International license .

Table 2. Journal funding models for the articles published by general and high-impact researchers

\begin{tabular}{|c|c|c|}
\hline & \multicolumn{2}{|c|}{ No., $(\%)$} \\
\hline & General researchers & High-impact researchers \\
\hline Total & 914 & 1471 \\
\hline $\begin{array}{l}\text { Article processing charge- } \\
\text { based journals }\end{array}$ & $384(42.0)$ & $426(29.0)$ \\
\hline Subscription-based journals & $57(6.2)$ & $169(11.5)$ \\
\hline Hybrid $^{\mathrm{a}}$ & $457(50.0)$ & $870(59.1)$ \\
\hline Unknown & $16(1.8)$ & $6(0.4)$ \\
\hline
\end{tabular}

Table 3. Article processing charges for all first and/or senior research and review articles published in 2019

\begin{tabular}{|c|c|}
\hline \multicolumn{2}{|c|}{ Median (Interquartile range) } \\
\hline $\begin{array}{l}\text { General } \\
\text { researchers }(\mathbf{n} \\
\quad=\mathbf{2 4 1})\end{array}$ & $\begin{array}{l}\text { High-impact } \\
\text { researchers }(n= \\
246)\end{array}$ \\
\hline $191(0,2500)$ & $2900(0,5465)$ \\
\hline $0(0,0)$ & $0(0,0)$ \\
\hline $0(0,0)$ & $2800(0,5181)$ \\
\hline $739(0,3950)$ & $5000(0,10879)$ \\
\hline $0(0,2500)$ & $2600(0,5465)$ \\
\hline
\end{tabular}

\begin{tabular}{|l|r|r|}
\hline Standard APCs paid per year, $\$$ & $191(0,2500)$ & $2900(0,5465)$ \\
\hline First author articles only & $0(0,0)$ & $0(0,0)$ \\
\hline Senior author articles only & $0(0,0)$ & $2800(0,5181)$ \\
\hline APCs paid per year (including hybrid journals) ${ }^{\mathbf{a}}, \mathbf{\$}$ & $739(0,3950)$ & $5000(0,10879)$ \\
\hline APCs paid per year (minimum) $)^{\mathbf{b}}, \mathbf{\$}$ & $0(0,2500)$ & $2600(0,5465)$ \\
\hline
\end{tabular}

APCs $=$ article processing charges

${ }^{a}$ A traditional subscription-based journal with a fee-based open access publication option

${ }^{\mathrm{b}}$ The minimum APCs paid is defined as the lowest possible APC an author could have paid given the discounts, membership options or licensing options listed on a journal website. 
medRxiv preprint doi: https://doi.org/10.1101/2020.12.16.20247643; this version posted December 18, 2020. The copyright holder for this preprint (which was not certified by peer review) is the author/funder, who has granted medRxiv a license to display the preprint in perpetuity.

It is made available under a CC-BY-NC-ND 4.0 International license .

Table 4. Standard article processing charges for first and senior research and review articles, across researcher characteristics

No. $\quad$ Median (IQR) $\quad \mathrm{p}-$

\begin{tabular}{|l|l|l|l|}
\hline No. & Median (IQR) & $\begin{array}{l}\text { p- } \\
\text { value }^{\mathrm{b}}\end{array}$ \\
\hline
\end{tabular}

Total APC per year $(\$)$

No. $\quad$ Median $\quad$ p-
(IQR) $\quad$ value $^{\mathrm{b}}$

\begin{tabular}{|c|c|c|c|c|c|c|c|}
\hline Gender & & & 0.48 & Gender & & & 0.20 \\
\hline Male & 109 & $300(0,2950)$ & & Male & 159 & $\begin{array}{r}2500(0, \\
5380)\end{array}$ & \\
\hline Female & 70 & $0(0,3502)$ & & Female & 82 & $\begin{array}{r}3145(0) \\
6387)\end{array}$ & \\
\hline Primary Affiliation & & & 0.36 & Primary Affiliation & & & 0.45 \\
\hline Academia/Hospital & 236 & $28(0,2500)$ & & Academia/Hospital & 213 & $\begin{array}{r}3000(0, \\
5526)\end{array}$ & \\
\hline Other & 5 & $\begin{array}{r}4420(3070 \\
6160)\end{array}$ & & Other & 31 & $\begin{array}{r}1870(0 \\
4950)\end{array}$ & \\
\hline Training $^{c}$ & & & 0.19 & Training $^{c}$ & & & 0.13 \\
\hline MD & 120 & $234(0,2983)$ & & MD & 166 & $\begin{array}{r}2454(0 \\
5355)\end{array}$ & \\
\hline PhD Only & 58 & $975(0,4679)$ & & PhD Only & 61 & $\begin{array}{r}3490(1695, \\
7150)\end{array}$ & \\
\hline Other Degrees only & 3 & $0(0,0)$ & & Other Degree & 5 & $0(0,4800)$ & \\
\hline Region & & & 0.32 & Region & & & $<0.001$ \\
\hline $\begin{array}{l}\text { Region of the } \\
\text { Americas }\end{array}$ & 62 & $0(0,2425)$ & & $\begin{array}{l}\text { Region of the } \\
\text { Americas }\end{array}$ & 144 & $\begin{array}{r}1695(0, \\
3935)\end{array}$ & \\
\hline Other & 179 & $225(0,2865)$ & & Other & 101 & $\begin{array}{r}4800(1888, \\
8290)\end{array}$ & \\
\hline H-Index (median) & & & 0.14 & H-Index (median) & & & 0.30 \\
\hline$\leq 11.0$ & 120 & $0(0,1390)$ & & $\leq 38.5$ & 123 & $\begin{array}{r}2500(0, \\
4800)\end{array}$ & \\
\hline$>11.0$ & 121 & $1302(0,4761)$ & & $>38.5$ & 123 & $\begin{array}{r}3465(0, \\
7494)\end{array}$ & \\
\hline $\begin{array}{l}\text { Years since first } \\
\text { publication } \\
\text { (quartiles) }\end{array}$ & & & 0.22 & $\begin{array}{l}\text { Years since first } \\
\text { publication } \\
\text { (quartiles) }\end{array}$ & & & 0.97 \\
\hline$<7.0$ & 62 & $0(0,925)$ & & $<14.3$ & 62 & $\begin{array}{r}2625(0) \\
4800)\end{array}$ & \\
\hline $7.0-15.0$ & 62 & $862(0,3165)$ & & $14.3-22.5$ & 61 & $\begin{array}{r}3000(0, \\
8000)\end{array}$ & \\
\hline $15.0-25.0$ & 63 & $300(0,4400)$ & & $22.5-32.0$ & 68 & $\begin{array}{r}3000(0, \\
6500)\end{array}$ & \\
\hline$>25.0$ & 54 & $0(0,3513)$ & & $>32.0$ & 55 & $\begin{array}{r}2800(0 \\
4875)\end{array}$ & \\
\hline
\end{tabular}

$\mathrm{MD}=$ doctor of medicine; $\mathrm{PhD}=$ doctor of philosophy

${ }^{a}$ Unknown values were considered as missing for these analyses; therefore, row amounts may not sum to column total

${ }^{\mathrm{b}}$ Calculated using Mann Whitney U or Mood's test as appropriate

${ }^{\mathrm{c}} \mathrm{MD}$, with or without other degrees; a PhD, with or without other degrees (excluding MD); or any other degrees 
medRxiv preprint doi: https://doi.org/10.1101/2020.12.16.20247643; this version posted December 18, 2020. The copyright holder for this preprint (which was not certified by peer review) is the author/funder, who has granted medRxiv a license to display the preprint in perpetuity.

It is made available under a CC-BY-NC-ND 4.0 International license .

735 
Generate random sample of journal articles

Sample One: All Clinical Medicine

Journals
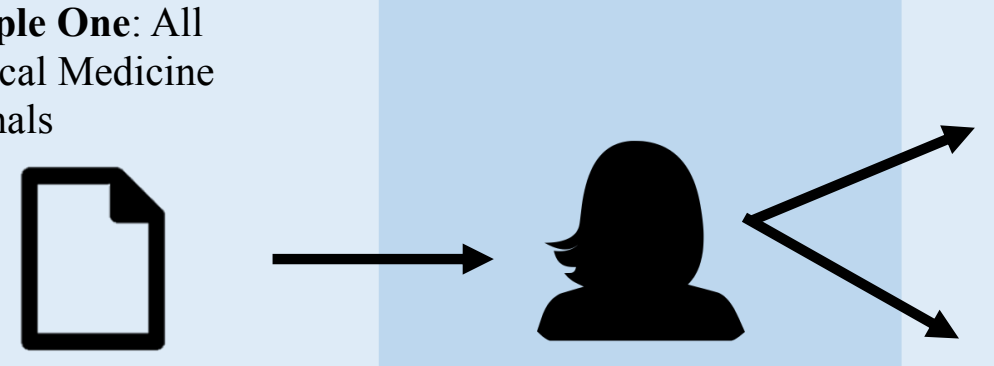

authors and author characteristics

\begin{tabular}{c}
\hline Identify \\
manuscripts \\
published in 2019
\end{tabular}

Extract the journal each article was published in
Investigate if there any APCs for that journal
Estimate how much a researcher pays in APCs, on average,

in a given year

General Researcher
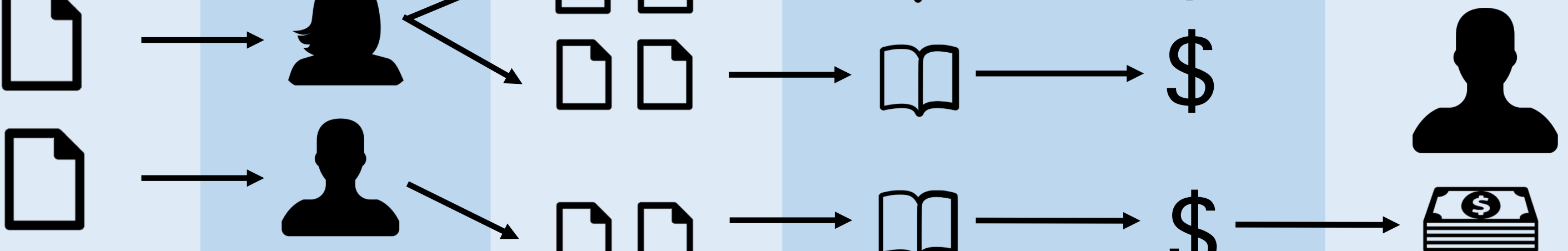

마
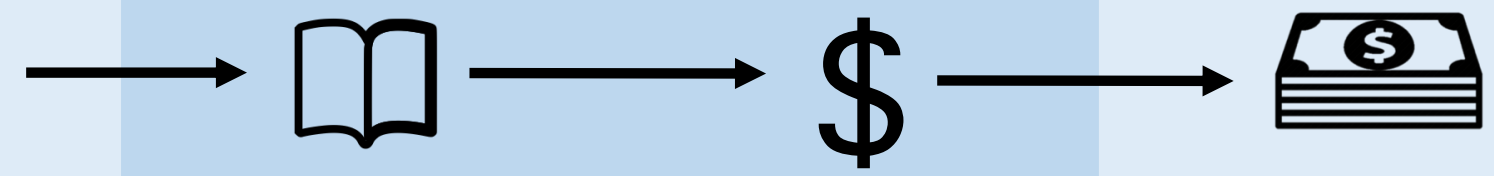

Sample Two: HighImpact Clinical

Medicine Journals
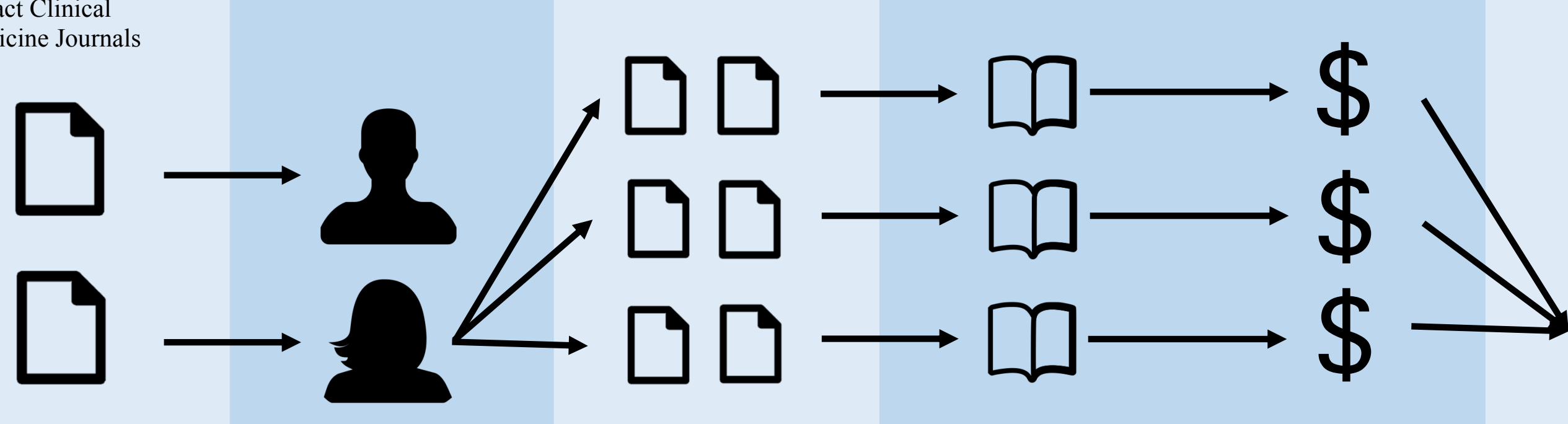

High-Impact Researchers

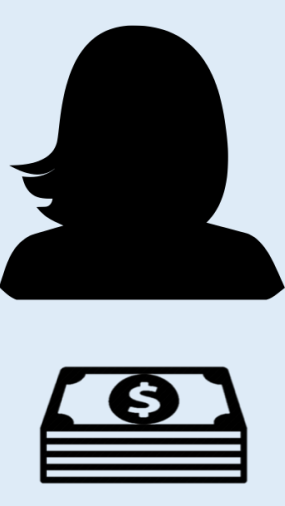




\section{Other ways to spend your} grant money:

\section{Total APCs paid by researchers (US Dollars)}

PhD Student tuition $\sim \$ 27,500$

Part-time project manager $\sim \$ 21,500$

New laboratory equipment $\sim \$ 15,000$

Personal SAS license $\sim \$ 8,700$

Domestic US conference attendance $\sim \$ 1,500$
General researchers

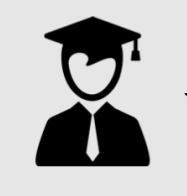

8

要
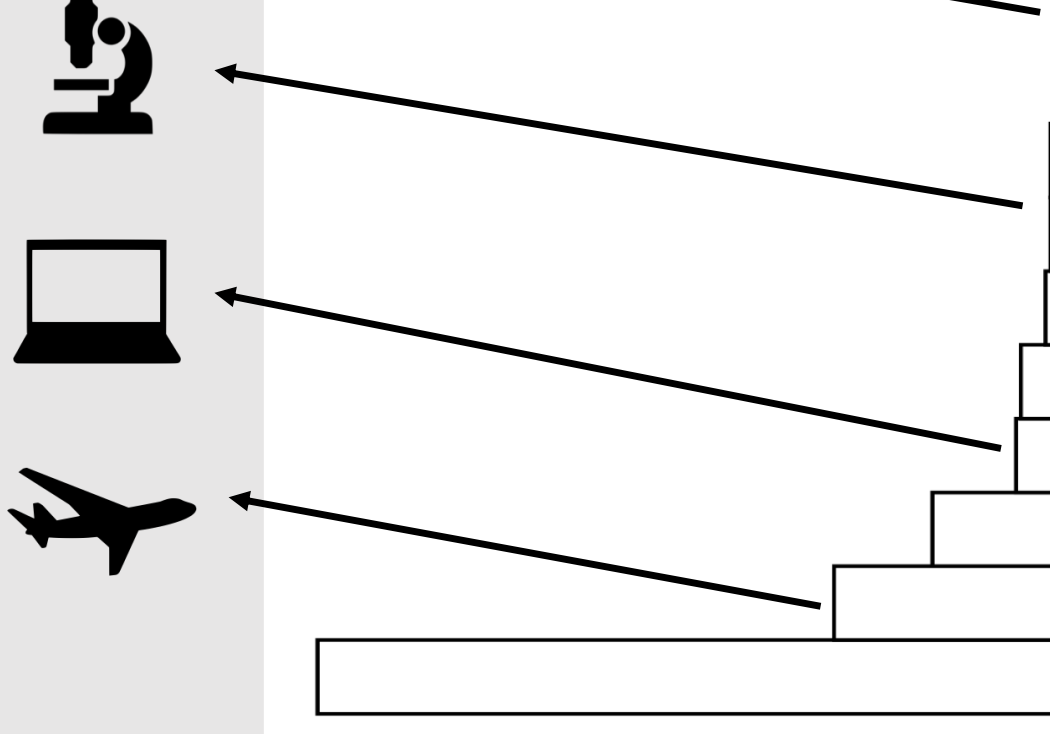

$\overline{150}$

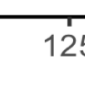

125
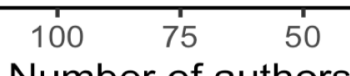

25

Number of authors

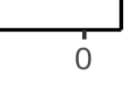

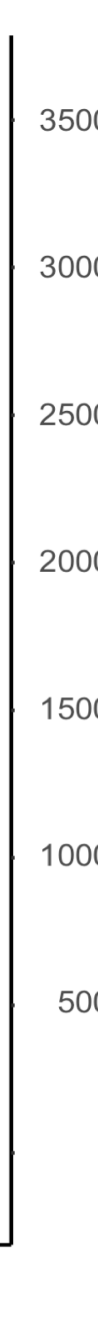

High-impact researchers

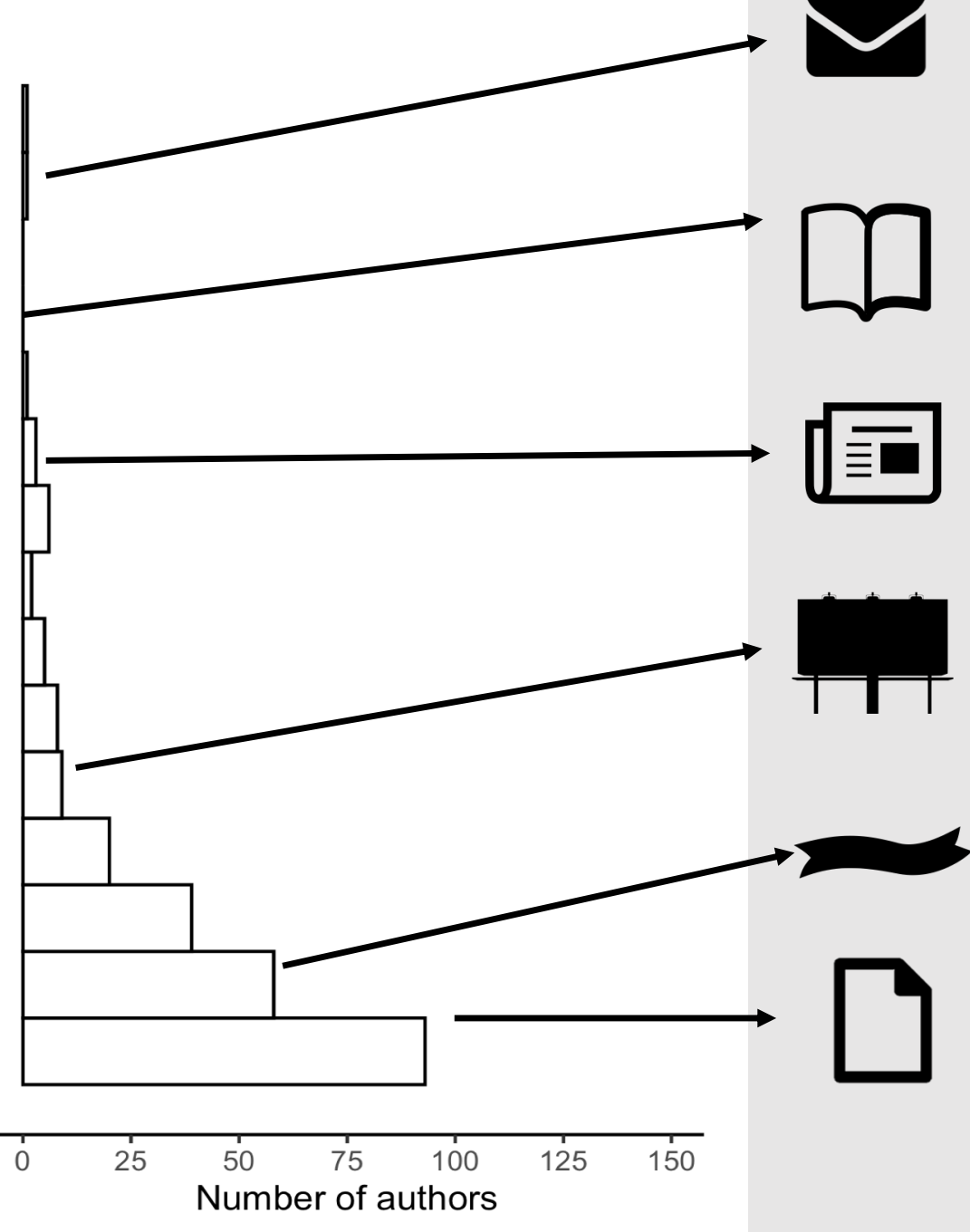

Mailing your paper to

the top research

universities in the US,

Canada and Europe $\$ 30,500$

A 3-page ad in the New

England Journal of

Medicine $\sim \$ 27,000$

Full page

advertisement in The

Guardian \$22,500

A billboard in London for three months $\sim \$ 11,000$

Airplane banner with your abstract $\sim \$ 3,200$

Publishing on a pre-print server or open access archive $\sim \$ 0$ 

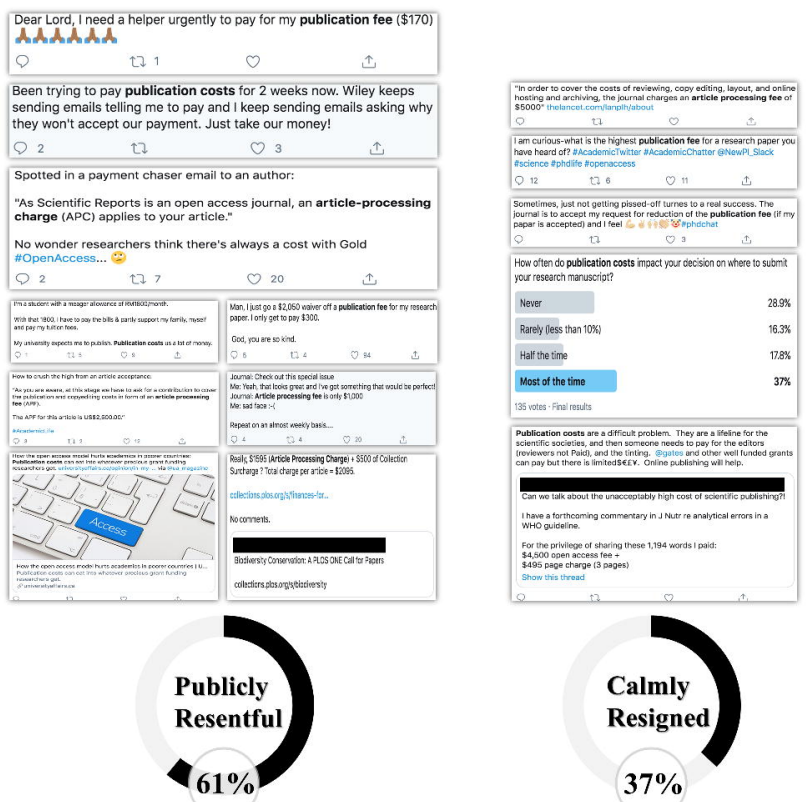

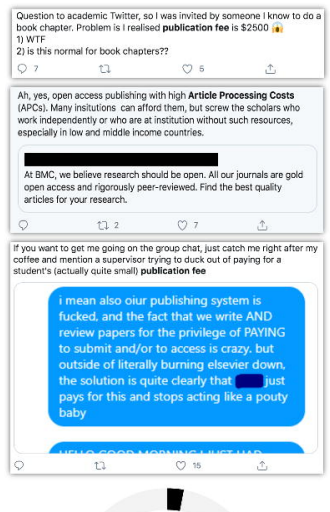

Publicly Opposed

$1.5 \%$
In my experience, at present APCS barely cover costs, although this will publication costs are a smal percentage of research budgets.

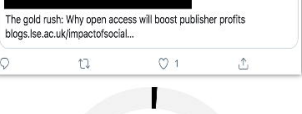

Publicly Grateful

$0.5 \%$ 